\title{
Development of Small Holder Plantation Forests: An Analysis from Policy Process Perspective
}

\author{
Hariadi Kartodihardjo ${ }^{1 *}$, Bramasto Nugroho $^{1}$, Didik Suharjito ${ }^{1}$, Ahmad Dermawan ${ }^{2}$ \\ ${ }^{1}$ Department of Forest Management, Faculty of Forestry, Bogor Agricultural University, Academic Ring Road, Campus IPB \\ Dramaga, PO Box 168, Bogor 16680, Indonesia \\ ${ }^{2}$ Center for International Forestry Research, Situgede, Sindang Barang, West Bogor, Bogor 16680, Indonesia
}

Received May 23, 2013/Accepted June 17, 2013

\begin{abstract}
This research was conducted to learn the inhibiting factors for renewal of forest utilization policy, particularly the policy of small holder plantation forests/HTR), by government. To achieve the objective of this research, there were studies on contents of law and regulations, respond of stakeholders toward those law-regulations, and problem of contents and constraints of law and regulations improvement through analysis approach of policy making process. It was found that technical constraints in HTR development were weak provision of forest territory and poor institutional strengthening of the participant community to be ready to receive permit or fund for HTR development. Such phenomena were due to contents of HTR policy which have more tendencies to answer the problem of absence of bureaucracy and administration procedure which should be determined on the basis of authorities of agencies of central and local government, rather than answering the problem faced by HTR participant community. Policy narrative in the past period in implementing large business policy of natural forest utilization were still dominant, accompanied with weak consideration in making and implementing policy toward forest territory conflict and weak socio-economic and bargaining position of the community, resulting in expensive public service which could not fulfill the community's need.
\end{abstract}

Keywords: policy making process, institution, policy narrative, small holder plantation forests

*Correspondence author, email: hkartodihardjo@yahoo.com, telp.+62-811-1933-83,fax.+62-251-842-1355

\section{Introduction}

The attention of Indonesian government to reallocate forest resource benefits has emerged since the change of Law No. 5/1967 to Law No. 41/1999 concerning Forestry. The policy after the creation of such new law opened several schemes of access and right opportunities for local community, namely in the form of permit of community based forest $(\mathrm{HKm})$ inside protection forest and production forest; permit of small holder plantation forest (HTR) inside production forest, and opportunity of forest management in the form of village forest and traditional forest (Hindra 2007). However, the developments of those items are very slow.

Up to the end of 2011, permits and rights of forest resources for local community were less than 700,000 ha. On the other hand, allocation of permits for large business which had ever reached 60 million ha in the year 1990s, at present is around 36 million ha (MoF 2012). Permit issuance of HTR which was started in the year 2007 through determination of location by forestry minister and confirmation of permit by regent or mayor, up to December 2011 comprised 67 permits with total area of 661,151 ha (MoF 2012).

Policy of domination by large business in the utilization of forest resources since the 1970s, has not only created unfair allocation of forest resource benefits, but also created constraints in the renewal of logical framework toward forestry development on the basis of community empowerment (Awang 2005). Adoption of new knowledge for improving policy toward that point also suffered constraints (Kartodihardjo et al. 2006). Forestry institutional aspect and administration of forest management by the government, or local region government, have not supported the strengthening of community institution or conflict resolution in relation with the running of small business of forest resources utilization (Ohorella 2003; Fahmi \& Zakaria 2005).

Constraints for development of social forestry have actually been known by decision makers (Kartodihardjo et al. 2006; Watala 2008). As stated by forestry ministry in the opening of workshop of "HTR development", December 2006, the concept of providing greater access toward the community in the form of HTR development, was compiled from learning process on programs or projects of community empowerment which have ever been implemented in the past $^{1}$. However, in actual situation, with performance which was still poor as has been described above, it seems that such learning process has never occured. 
This research was carried out for learning the constraining factors for renewal of law and regulation of utilization of forests, particularly those of plantation forests by local community (HTR $)^{2}$. In the second part of this article, there is presentation of research method. Social forestry and its performance are presented in the next part, followed by permit process of HTR, policy problems, discussion, and conclusion.

\section{Methods}

For understanding the content of HTR policy, content analysis is conducted on a number of law and regulations (Bungin 2001). Appropriateness of contents of policy is determined by problem of policy which has been defined (Dunn 2000). Policy could be understood not only from the mere textual contents of the law-regulation, but also from actions and reactions of the relation between the policy maker and the implementing parties of the policy (Shore \& Wright 1997). On the basis of this view, it could be suggested that the policy which is contained in the contents of law-regulation constitutes a norm and legal intention which should be executed.

Interpretation and implementation of those lawregulation are analyzed on the basis of views from various stakeholders through focus group discussion (FGD) and interviews with participant farmers of HTR. In South Kalimantan, FGD is conducted in Banjarbaru and in Tanah Laut Regency, namely in Asam Jaya Village, Jorong Subdistrict and Ranggang Village, Takisung Subdistrict. Interviews were carried out to with 28 farmers. In Riau, FGD was conducted in Pekanbaru, in Subdistrict of Logas Tanah Darat, District of Kuantan Singingi. There were also interview with Forestry Service Agency of Kuansing Regency (26 farmers).

For understanding the logical framework in the decision making during policy making of HTR, there was usage of historical institutionalism approach (Peters 2000; Steinmo $2008)^{3}$. On the other hand for studying further the creation of that HTR policy, there was analysis on policy narrative ${ }^{4}$ being embraced by policy makers and on the interests of the policy makers or other involved parties (Sutton 1999; IDS 2006), including the possibility of existence of policy maker which is trapped (Fox \& Staw 1979). Such action and reaction constitute the background for creation of a policy and will produce performance whose success rate could be measured.

\section{Results and Discussion}

Poor performance of HTR Actually, the development target of HTR, for period up to the year 2016 is as large as 5.4 million ha or around 600,000 ha year ${ }^{-1}$. However, this policy which emerged for the first time in the year 2012 has not achieved the target. In the report of MoF (2012) it was mentioned that up to December 2011 there had been issuance of Forestry Minister Decree for 67 HTR permit as large as 661,151 ha.

Complicated process of HTR permit issuance The main content of regulation for permit issuance of $\mathrm{HTR}^{5}$ and scheme of funding are described briefly as follows:
1 For determination of HTR location, there are at least involvement of 9 work units and 25 steps. After the location has been established, farmer group/ cooperative/individual person should convey request application for permit by following 29 steps, and for following those steps there should be contact with 10 work units/institutions. Procedure of location establishment and HTR permit issuance could be seen in Figure 1.

2 Request application for permit is submitted to village chief and the village chief conduct verification to forward it further to regent/mayor. Agency for Monitoring of Production Forest Utilization (BP2HP) provides technical consideration after conducting verification on administrative aspects. If there have been conformity in all those steps, regent/mayor issue permit for business of wood forest products utilization (IUPHHK)-HTR - with duration of 60 years and could be extended one time for 35 years.

3 Funding could be obtained on the basis of pattern of financial management of public service agency for financing forest development. Permit holder could conduct activities in accordance with the permit, obtain easy process to get fund for financing the development of HTR, obtain technical guidance and extension service, and obtain forest product marketing opportunity. Permit holder is obliged to compile annual work plan which could be prepared by BP2HP or by consultant which works in the field of forestry or by non governmental organization, with funding from government.

Complicated funding procedures With the target of 5.4 million ha for period up to the year 2016, development of HTR is projected to need fund as much as Rp43.2 trillion (DG-FPD 2007). Distribution of this fund is conducted in revolving ${ }^{6}$ manner to farmer groups ${ }^{7}$, with maximum period of 8 years and does not require collateral, but there is guarantee in the form of plant yield, personal guarantee, and farmer group's guarantee. Interest of the loan is determined as large as the interest imposed by Deposit Guarantee Institution (Indonesia's state-owned deposit insurance corporation) which ranges $7-10$ per year.

Such financing scheme also requires the existence of farmer group with minimally 5 members, and each member should manage forest of at least 8 ha. Such farmer group should be endorsed by village chief and under attention of chief of service agency who handles forestry affairs in the regency/municipality. The farmer group should get accompanying process by accompanying agent which is appointed by regent/mayor. The process of request application and fund distribution require 20 steps and involve 9 institutions ${ }^{8}$.

Respond toward policy Respond of stakeholders toward HTR policy is obtained through FGD and interview with farmers, with the following results:

1 Relation between institutions, particularly in terms of the use of forest territory, funding, or the role of forestry extension agents ${ }^{9}$ was still very weak. There was still differences in understanding and interpreting the policy 


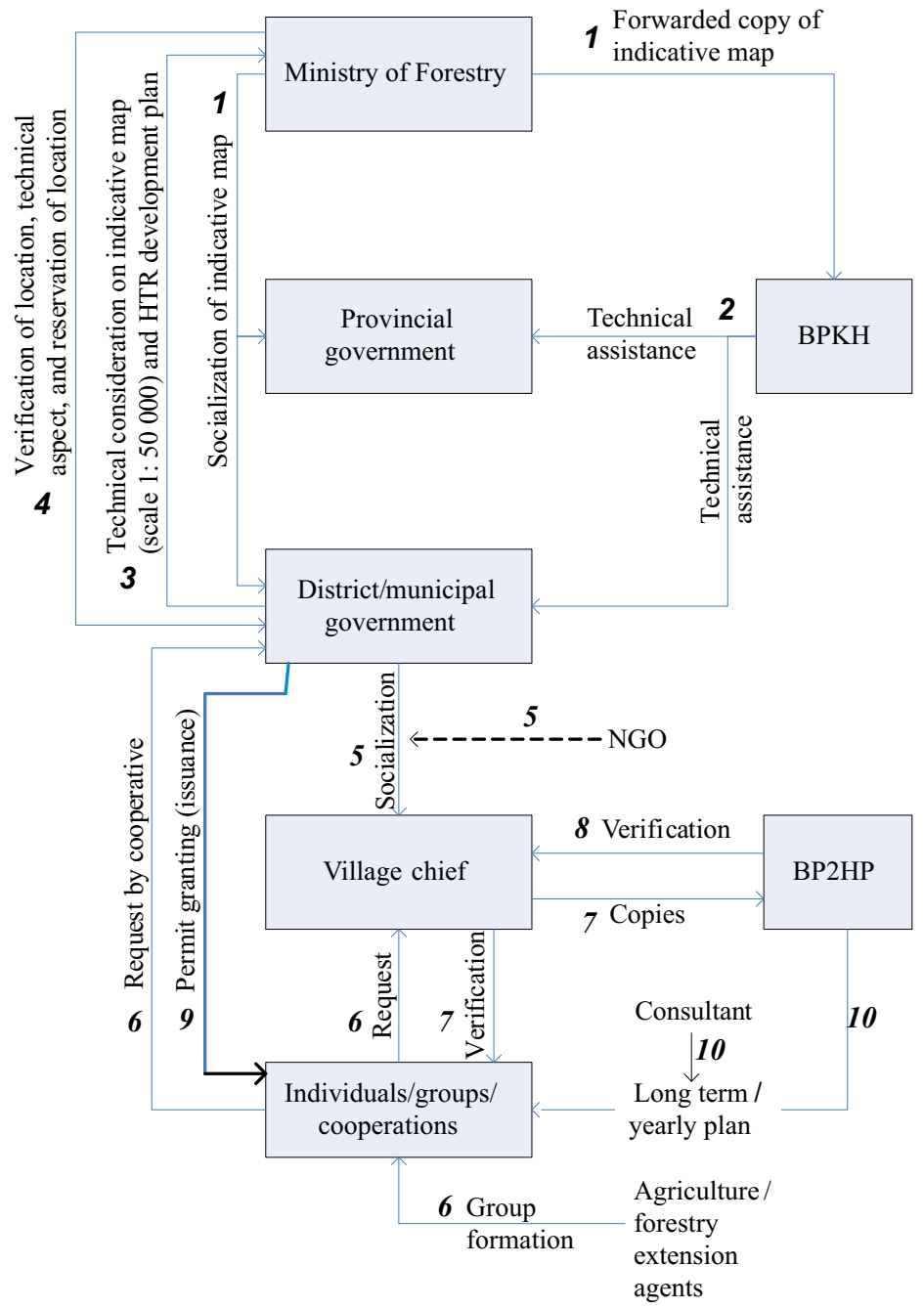

Figure 1 Procedure of establishment of location and permit issuance of HTR Development. BPHK=Agency for Forest Territory Establishment; BP2HP = Agency for Monitoring of Production Forest Utilization; number expressed sequense lincensing process to work.

of HTR. For completing the location preparation and implementing the procedure of permit issuance ${ }^{10}$, Forestry service agency did not have sufficient budget;

2 Forestry service agencies, both in the province and in the regency, shared the opinion that the law and regulations for plantation forest development in state forest territory were too complicated. In general, the community was assessed by local government as has not been ready to implement the regulation, either in terms of permit issuance process, compilation of planning documents, development of plantation forest or of wood trading scheme. On the other hand, the community considered that for obtaining and implementing the permit, there was a need for extension agent, while in this case the role of extension agent was very small or even none;

3 Availability of capital became the main constraint for the community (Nugroho et al. 2010). Besides that, lack of experience in operating commercial activities and organization and managing financial affairs, became also the primary constraint;
4 In the case of partnership with big company, generally the community groups/ cooperatives have not been able to represent the interest of their members, particularly in terms of product sharing of harvest yield, wood price, and settlement of land conflict. Besides that, the settlement of problems related with sustainability of wood supply and quality had not been able to be conducted by community groups/cooperatives, so that this became constraints for the partner company

5 In the case of credit, generally the community members did not obey to the obligation for repaying the loan, due to past experience where people who were in arrears in credit repayment, did not receive penalty, or even be forgiven;

6 In the execution of plantation forest development by people community, particularly outside Java island, wood market which is freely open, generally has not been formed. This phenomenon was revealed, during discussion both in Banjarbaru and in Pekanbaru. Therefore, partnerships between big company and the 
community are often aimed at creating wood market through contract.

Policy problem Content analysis of policy is presented in relation with responds of stakeholders toward policy problems of HTR development and contents of law and regulations. On the basis of such analysis, policy problems could be categorized on substantial basis and on stakeholder's interest basis.

1 Government problem in providing right and access for local community in social forestry, is in general constrained during determination of location (Noordwijk et al. 2007). This is because the government does not have its own framework for determining the location of HTR, and in this case the search of location is assigned to the prosess of permit issuance ${ }^{11}$. Such condition follows the pattern of policy of location determination for big company since the year 1970s, where the transaction cost of location determination was shouldered by the big company (Kartodihardjo 1998; Mardipriyono 2004; APHI 2010). However, in the case of HTR, if the communities, including the prospective holders of HTR permit, were also charged with the cost of location determination, this was proven as problematic ${ }^{12}$.

2 Problem of coordination development of HTR at local regional level, which was related with spatial arrangement, community empowerment and infrastructure development (such as road and market), could not be conducted only by forestry sector. Forestry Service Agencies at the province and regency of the study location have felt such problem. Although there were law and regulations concerning the HTR development policy, but they were not accompanied with working apparatus to make such law-regulations be executed. Also, in relation with the aspect of capital, existence of Forestry BLU (Public Service Agency) has not been able to make the funding policy operable. As a result, the preparation to make the community feasible to receive the credit, has not been handled by any party.

Meanwhile, the farmers wanted to improve the steps of policy implementation which were related directly with strengthening the capacity of the community, planting preparation, or the production factor. For this purpose, there was a need for accompanying agents which directly accompany the daily steps of farmer's work, education, and training. In this case, plantation forest company which had partnered with farmers, mentioned the need for a third party which could conduct mediation of conflicts which are related either with rights over forest land or with establishment and execution of contract.

The background of government in HTR development, besides being encouraged by national policy of pro-poor, pro-job, and pro-growth is also encouraged by the previous policy of social forestry development which was directed toward developing people entrepreneurship and their commercial business, and development of incentive system (Rusli 2003). Consideration toward local condition where the people community are residing, is necessary to minimize the so called "elite capture". However, development of social forestry is not for changing the status and function of forest territory,and also not for giving ownership of forest territory (Rusli 2003b).

Other government official declared that social forestry constitutes an approach of conflict resolutions, particularly which is related to forest territory (Pasaribu 2003). Experience shows that many local governments used the concept of social forestry not for the people community, but for particular group only (Pasaribu 2003). Such statement which was related with problem of governance was strengthened again by Forestry Minister during the launching of HTR program in the year $2007^{13}$.

The government's statement as described above seems to reflect the commitment which was accompanied with deep knowledge for developing social forestry, particularly HTR. With the progress of time, constraints in implementing the policy are described as follows.

The low achievement in the performance of HTR or social forestry showed that there was no policy made to overcome problems. Contents of ministerial regulation concerning procedures of request application for business of wood forest products utilization in HTR, as described above had more tendency to determine the administration process of location determination and permit issuance of HTR, without considering the prerequisites to make the location determination and permit issuance run smoothly.

In discussion of National Level Forestry Plan ${ }^{14}$, there were revelations of main problems of claim and overlapping of state forest territory utilization. These problems are originated from spatial arrangement problem, overlapping problem of permit location determination, existence of village in state forest territory, or claim of ownership by traditional community or other local communities. The second point is that the implementation of permit issuance policy which requires lengthy procedure and time is also a constraint. Weak institution, which is mainly related with capacity and efficiency of forestry governance administration implemented by service agencies which handle forestry affairs in local regions, become also a source of problem.

The third point is that it can be ascertained that the granting of rights and access to community, without any strengthening of institution and accompanying process of the community, tend to suffer failure. Several constraints of social forestry development which had been studied by policy makers were due among other things to:

1 absence of adoption of forest management practices which had run for a long time;

2 programs executed by government, state owned business agency (BUMN) and private companies emphasize administrative responsibility, rather than the actual development in the field, and;

3 existence of assumption which equate local communities with large companies.

This phenomenon is confirmed further by Affandi (2005) which explained that in relation with the use of capital for its business, the local community lack of access to information and support in negotiation with capital owner, resulting in agreement which put the community in disadvantaged condition. This phenomenon was similar with what occurred in Central Maluku (Ohorella 2003), or with execution of 
wood utilization by community cooperative (Kopermas) in Papua (Yulianti 2005).

This study shows that policy of HTR development without relating it with efforts of improving forestry governance and community empowerment is proven as not being able to proceed. Weak ability of government and local region government in strengthening the institutional aspects of local community is supposed probably due to absence of substantial efforts to take side to appropriate party, such as the inaction toward the existence of business competition with free fight liberalism and the rampant conflict of interest which put the community in disadvantageous condition. In this case, the practice of forest land allocation still has the tendency to be directed to large companies, not to local community $^{15}$.

According to interview results with government official $^{16}$, the lengthy bureaucratic arrangement for permit issuance is not intended to burden the prospective permit holders. The reason for this is that the government should work in accordance with law and regulations so that such form of permit issuance is inevitable. Also, the local government should be involved in the process of permit issuance because this has been regulated in Government Regulation No 38/2007 concerning the authority of central and local government in the implementation of permit issuance. The phenomenon that it is afterwards known that such administrative procedure constitutes in fact the main factor which cause the impeded implementation of the policy, is not considered and is not resolved in the policy.

Policy narrative and the trapped administrator The issue of administration procedure to obtain access of forest resources benefit and capital facilities is part of the issue of forestry governance. In other words, in the process of policy making of HTR development, there is the actual problem which is not perceived and is not reflected by the decision makers, and such actual problem is indeed occurring inside the government itself ${ }^{17}$. This phenomenon is supported by policy narrative and mainstream of researches or forestry discussions in Indonesia, which in general define that the obstacles/constraints of social forestry are only around the technical and economic problems (Kartodihardjo et al. 2006).

Policy narrative affect not only individuals, but also produce individuals which have strong desire to conduct a series of efforts which they believe as the appropriate actions (Foucault 1980). Technical and economic problems which become obstacle for HTR as framework of policy makers, have produced subjects of policy makers which are obsessed to solve technical and economic problems in HTR development and do not give enough attention to other problems which indeed constitute the series of main causes or roots of the problems. Meanwhile, tenurial and empowerment problems in social forestry constitute the main policy narrative in the circles of civil community organization which grow rapidly since the year 2000s. This narrative produces subjects of activist of civil community organization who continuously put forward these 2 aspects in a series of communication process with administrator/policy makers.
Based on situation described above, various ideas from technical and economic discussion of forestry problems and their recommended solution are not considered as sufficient for policy renewal because the problems are not only of those phenomena. It turns out that the problems faced up to now is not the absence of knowledge and information which are needed for policy renewal, but the weakness of precondition, procedure or logical framework which allow such knowledge and information be able to be adopted as basis for policy renewal and field practical works (Kartodihardjo 2006; Lackey 2007).

Besides that, there is also strong indication that the behavior of policy maker administrators is being trapped, so that although they agree with policy improvement, but their actions are contrary to that improvement, and they will also join the process of inhibiting the policy improvement, when it is predicted that there are consequences which will be less beneficial for them ${ }^{18}$ (Fox \& Staw 1979). Finally, the trapped administrators seem to have no other choices, but to practice again the old habits such as maximizing the budget (Niskanen 1968; Kartodihardjo 2006) and lengthening the bureaucracy of public service which cause high cost economy ${ }^{19}$.

This policy maker administrators which are being trapped, actually possesses knowledge and information for designing the strategy of community empowerment for HTR participant community, but it appears that there have been occurring a selection process over such knowledge and information, where knowledge and information which are considered as not supporting their way of thinking, will not get attention or will be marginalized ${ }^{20}$. Process of marginalization of particular knowledge and information which is conducted by policy maker administrators constitutes a part of the process for developing discourse which is in conformity with their interest (Foucault 1980).

Other factor which is supposed probably to also affect the stagnant condition in policy renewal is the way of thinking which always burdens the permit holder to arrange all location determination and permit issuance administration as manifestation of transaction for various interests, and such way of thinking has not disappeared yet. It has been existed since the existence of policy of natural forest concession in the year 1970s and is still prevailing up to the present time (Ismanto 2010).

Such situation is in accordance with the approach of historical institutionalism where Peters (2000) mentioned the existence of "path dependency", which is a close relation of past discourse with implementation of new policy in the next period. This is also not unrelated with the "renewal" motive of policy which is dominantly generated by government, which tends to be encouraged more by intention to fulfill the need of regulation at higher level, rather than to respond to the need of public service (National Forestry Council 2008).

\section{Conclusion}

From the previous discussion, it can be shown that the HTR policy being produced contains substantial problems caused by the bureaucratic resistance and could not use the previous experiences and knowledges of the issues 
encountered in social forestry implementation in general. Technically, the main constraint in the development of HTR is the weakness of policy implementer in providing forest territory and in preparing participant community to be ready to obtain permit and funding for HTR development. This implies that there is a need for mobilization of resources for the policy implementer to directly handle the technical works. Mobilization of such resources faced constraints because, the contents of HTR policy did not answer the problems faced by policy implementers, and most HTR participants were unable to complete various administrative procedures required. Meanwhile, the policy makers were accustomed to serve large companies that can afford, so that obstacles of administrative procedures for HTR participants were indeed beyond their calculation. As a result of trapped administrator phenomenon, information regarding experience of failure and successes in the previous social forestry implementation, are not always utilized as arguments for policy formulation of HTR. There was difference in orientation between central and local government. Existence of political will of government with the establishment of HTR policy is not always considered important by local government. The process of policy renewal in the future tends not to be able to be conducted in stages (incremental policy change), but be conducted fundamentally, and there is a need for innovation from outside the organization to push toward such policy renewal.

\section{Acknowledgments}

The authors express their thanks to CIFOR as partner in this research, Prof. Wahyu Andayani, Diah Raharjo, Mia Siscawati, Asep Sugih Suntana, and Christine Wulandari for their inputs and literature information that they provide; also to Entin Hendartin and Tuti Herawati for their help in field survey and interviews.

\section{References}

Affandi O. 2005. Dampak Kebijakan IPPK dan IUPHHK Terhadap Perekonomian Masyarakat di Kabupaten Malinau. Governance Brief No 12. Forests and Governance Programme. Bogor: CIFOR.

[APHI] Indonesian Association of Forest Utilization. 2010. Kinerja Pengawasan Pengusahaan Hutan oleh Pemerintah. Palangkaraya: Indonesian Association of Forest Utilization.

Awang SA. 2005. Sejarah pemikiran pengelolaan hutan Indonesia. Wacana 20(6): 13-48.

Baginski OS, Soussan J. 2005. A Methodology of PolicyProcess Analysis: Livelihood-Policy Relationship in South Asia. Working Paper 9. United Kingdom: Department for International Development.

Bungin B. 2001. Content Analysis dan Focus Group Discussion dalam Penelitian Sosial di dalam Metodologi Penelitian Kualitatif: Aktualisasi Metodologis ke Arah Ragam Varian Kontemporer. Jakarta: PT. Raja Grafindo Perkasa.
[DG-FPD] Directorate General of Forestry Production Development. 2007. Perkembangan Pembangunan Hutan Tanaman Industri. Jakarta: Kementerian Kehutanan RI.

[DKN] Dewan Kehutanan Nasional. 2008. Meniti Langkah Membangun Pilar Kehutanan: Prioritas Revisi Regulasi Pengelolaan Hutan Alam dan Hutan Tanaman. Jakarta: DKN

Dunn WN. 2000. Public Policy Analysis: An Introduction. Second Edition. New Jersey: Prentice-Hall, Inc.

Fahmi E, Zakaria Y. 2005. Good governance dan multistakeholder process: minus malum dalam wacana liberal? Wacana 20(6): 93-111.

Foucault M. 1980. Power/Knowledge, Selected Interviews and Other Writings 1972-1977. New York: Pantheon.

Fox FV, Barry MS. 1979. The trapped administrator: effects of job insecurity and policy resistance upon commitment to a course of action. Administrative Science Quarterly 24(3): 449-471.

Hindra B. 2007. Community Forestry in Indonesia. Paper presented on Asia Pacific Tropical Forest Investment Forum 6-8 August 2007. Bangkok: Asia Pacific Tropical Forest Investment Forum.

[IDS] Institute of Development Studies. 2006. Understanding Policy Processes: A Review of IDS Reseach on the Environment. United Kingdom: University of Sussex.

Ismanto AJ. 2010. Kelembagaan dan kebijakan pengelolaan hutan alam produksi [dissertation]. Bogor: Graduate School Bogor Agricultural University.

Kartodihardjo H. 1998. Peningkatan kinerja pengusahaan hutan produksi melalui penataan kelembagaan [dissertation]. Bogor: Graduate School Bogor Agricultural University.

Kartodihardjo H. 2006. Masalah kapasitas institusi dan arah kebijakan kehutanan. Jurnal Manajemen Hutan Tropika 12(3):14-25.

Kartodihardjo H, Suparji, Beni FS, Saleh MB. 2006. Refleksi Kerangka Pikir Rimbawan. Bogor: Alumni Fakultas Kehutanan, Institut Pertanian Bogor.

Lackey RT. 2007. Science, scientists, and policy advocacy. Conservation Biology 21(1): 12-17. http://dx.doi.org/ 10.1111/j.1523-1739.2006.00639.x.

Mardipriyono B. 2004. Biaya transaksi dan pengaruhnya dalam pengelolaan hutan produksi lestari [thesis]. Bogor: Graduate School Bogor Agricultural University.

[MoF] Ministry of Forestry. 2009. Rencana Kehutanan Tingkat Nasional, 2010-2029. Jakarta: Kementerian Kehutanan RI. 
[MoF] Ministry of Forestry. 2012. Statistik Kehutanan Indonesia 2011. Jakarta: Kementerian Kehutanan RI.

Niskanen WA. 1968. The peculiar economics of bureaucracy. American Economic Review 58(2): 293-305.

Noordwijk M van et al. 2007. Is Hutan Tanaman Rakyat a New Paradigm in Community Based Tree Planting in Indonesia? ICRAF Working Paper Number 45. Bogor: World Agroforestry Centre.

Nugroho B, Hariadi K, Didik S, Entin H. 2010. Analysis of Finance Institution to Support Small Holder Plantation Forest Development in Indonesia. Bogor: Bogor Agricultural University and CIFOR.

Ohorella A. 2003. Penguatan institusi pengelolaan hutan alam produksi dalam rangka otonomi daerah di Maluku Tengah [thesis]. Bogor: Graduate School Bogor Agricultural University.

Pasaribu H. 2003. Majalah Kehutanan Indonesia. Edisi: Juni. Jakarta: Kementerian Kehutanan RI.

Peters BG. 2000. Institutional Theory: Problems and Prospects. Political Science Series 69. Vienna: Institute for Advanced Studies.

Rusli Y. 2003a. The policy of ministry forestry on social forestry. Paper is presented in International Conference on Rural Livelihood, Forests and Biodiversity, 19-23 May 2003. Bonn.

Rusli Y. 2003b. Majalah Kehutanan Indonesia. Edisi: Juni. Jakarta: Kementerian Kehutanan RI.

Shore C, Wright S. 1997. Policy: A new field of anthropology. In: Shore C, Wright S, editors. Anthropology of Policy: Critical Perspective on Governance and Power. London and New York: Routledge.

Sutton R. 1999. The Policy Process: An Overview. Working Paper 118. London: Overseas Development Institute.

Steinmo S. 2008. What is Historical Institutionalism? In: Porta DD, Keating M, editors. Approach in Social Science. Cambridge UK: Cambridge University Press.

Watala. 2008. Studi Kolaborasi: Mendukung Hutan Kemasyarakatan secara Lebih Adil dan Demokratis di Lampung. Bandar Lampung: Watala.

Yulianti A. 2005. Kopermas: Masyarakat Hukum Adat sebagai Tameng bagi Pihak yang Berkepentingan. Governance Brief No 9. Forests and Governance Programme. Bogor: CIFOR.

\section{End Notes:}

${ }^{1}$ It is stated in the text of Forestry Minister speech that forestry ministry has learnt from experiences in the implementation of forest village development program (Program Bina Desa Hutan), partnership program (such as forest management together with the community (PHBM)/managing forest together with the community (MHBM)/people forest with partnership pattern (HRPK) by forest concession /IUPHHKHA/HT, foreign technical cooperation projects (such as social forestry/forestry ministry-GTZ in Sanggau, West Kalimantan, Multistakeholders Forestry Programme Forestry MinistryDFID), and several other projects of community empowerment in forestry ministry.

${ }^{2}$ This activity is part of the research "Strengthening Rural Institutions to Support Livelihood Security for Smallholders Involved in Industrial Tree-planting Programs in Vietnam and Indonesia". Researh cooperation by CIFOR, BMZ-Germany, CeTSAF-Germany, Humboldt University- Germany, Faculty of Forestry IPB-Indonesia, and FSIV-Vietnam.

${ }^{3}$ This approach assumes that human behavior is based not only on rational options (logic of consequentiality), but also on harmony (logic of appropriateness) by considering the situation and context being faced. This approach does not believe that someone will simply be considered as obedient toward law, or be considered as logical actor which will utilize legal stipulations for maximizing the fulfillment of his/her desire. This approach has more tendency to answer the question on why a certain option is made and why a certain result is obtained (Steinmo 2008)

${ }^{4}$ Policy narrative is a story that having beginning, middle and end outlining a specific cource of event which has gained the status of conventional wisdom within the development arena. Tragedy of the common, for example, is policy narrative (Sutton 1999; Baginski \& Soussan 2005).

${ }^{5}$ As had been described in Ministry Regulation No. 23/KptsII/2007 jo No. 5/Kpts-II/2008 concerning Procedure of Request Application of Permit for Business of Utilization of Wood Forest Products in HTR in Plantation Forest.

${ }^{6}$ Decree of Chief of Center of P2H No.01/Pusat P2H-1/2008 concerning Procedure of Request Application, Distribution and Repayment of Revolving Fund Loan for HTR Development.

Ministry Regulation No. P.9/Menhut-II/2008 (Forestry Minister Regulation) concerning The Requirement for Farmer Group to obtain Loan of Revolving Fund for HTR Development.

${ }^{8}$ Decree of Chief of Center of P2H No.01/Pusat P2H-1/2008 concerning Procedure of Request Application and Distribution of Revolving Fund Loan for HTR.

In discussion in Banjarbaru, South Kalimantan, regency forestry service agency explained that socialization of HTR policy has not been conducted because the implementing regulation has not been clear yet. On the other hand, Agency for Monitoring of Production Forest Utilization/BP2HP (Central Technical Implementation Unit) explained that such guidelines have been clear. Meanwhile, chief of Takisung subdistrict said that not all forest land should be planted with wood, because there was a need for land to be planted with food crops. Such statement was of course in contrary with the allocated use of forest territory which does not allow the planting of food crops, as stated by forestry service agency. Problem of relation between institution was also found in extension activities. The extension agents said that they have never been involved in HTR development by forestry service agency, while forestry service agency stated that the extension agents have never come to its office.

${ }^{10}$ In South Kalimantan, there were 6 locations which were 
proposed by Forestry Minister as areas reserved for HTR, 4 of those locations which were as large as 16,823 ha in the regency of Hulu Sungai Selatan, Tabalong, Banjar, Tanah Laut, have obtained decree of reservation. On the other hand, reserved area as large as 13,486 ha in Riau still exhibited overlapping problem with other uses. From the results of field checking by forestry service agency, it was known that location in the village of Logas, Sengingi Subdistrict, as large as 1,206 ha had been controlled by local people community.

${ }^{11}$ Indicative map which was circulated by Directorate General of Forestry Planology was still general in its feature and had not provided certainty in the location of HTR. Verification which was conducted by Regent, BPKH, and Village Chief (Figure 1) obliged the process to detail the information from map with scale between 1:250,000 and 1:100,000 into those between $1: 10,000$ and 1:5,000. Such change in map scale would result not only in requirement of particular technology and working procedure to produce the required map, but also in change of legalistic acknowledgement by the state to legitimate acknowledgement by the community. In the article $1 \mathrm{~A}$ and article 2 Ministry Regulation No 5/Kpts-II/2008 (Minister regulation) there are stipulations on the procedure of such location determination. In this case, the transacton cost for location determination was internalized in the process of HTR permit issuance.

${ }^{12}$ In discussion with 16 BP2HP all over Indonesia on 20 May 2010 it was revealed that the proposal of location and permit for HTR requires extra cost which range from Rp 6 million for personal permit to Rp600 million for permit in the form of cooperative. This cost is used for making the required maps, as well as for transportation, meeting with local region officials, and honorarium of the local region officials.

${ }^{13}$ Message of Forestry Minister on 27 Febuary 2007 in Semiworkshop and socialization of HTR to governor, regent, chief of Forestry Service Agency: "HTR is for people and it is not an artificial thing, and it is hoped very much that there is no any free rider. Therefore, local people or people around the forest should be empowered".

${ }^{14}$ Extracted from the results of discussion on draft of National Level Forestry Plan (RKTN) which had been conducted on 24 February 2009 in Jogjakarta, 3 March 2009 in Batam, 11 March 2009 in Jakarta, 24 March 2009 in Balikpapan, 15 April 2009 in Makassar, and 3 August 2010 in Jakarta.

${ }^{15}$ This fact is informed to Forestry Minister during discussion with Working Group on Forestry Ministry Policy on 13 January
2010. Prospective area of HTR whose reservation has been proposed by regency forestry service agency to forestry minister, in the case of South Kalimantan, was categorized as not productive (Ex-cultivated farm land) and there had been no any large private company which were interested. Probably, if there is large private company which is interested, Forestry service agency will have more tendency to give recommendation to large private company, rather than to HTR (Interview with participant of FGD in South Kalimantan on 17 March 2009).

${ }^{16}$ Results of interview with compiler/maker of HTR policy in forestry ministry, 11 February 2010 . This stipulation is in accordance with Article 4, Article 26 and Article 28, Law No. 41/1999 concerning Forestry.

${ }^{17}$ An echelon I official in forestry ministry only stated that such problems are consequences of multi-parties influence in Indonesia which was not possible to avoid. The bureaucracy problem itself was categorized by him as moral problem and had nothing to do with weakness of the system which operated on the basis of implementing regulations of law which was made by him. Interview on 14 January 2010 .

${ }^{18}$ Discussion on various efforts to overcome the problem of forestry ended up with conclusion that organization of forestry ministry also needs to be evaluated and rearranged in order to be able pursue again the various targets of forestry development in effective and efficient manner. However, such recommendation which is related with organization improvement is always rejected. Bureaucratic efficiency of public service is rejected because this will reduce or eliminate the transaction cost. This fact was revealed in the discussion on reorganization of forestry ministry, on December 2009January 2010.

19 From discussion with one of the large forestry businessmen on 1 April 2010, it was known that due to this fact, he should expend some reward in each desk during arrangement of permit issuance of forest utilization by his company. Such thing should be conducted if he wants to get faster service.

20 In depth interview with one of the Directors of Forestry Ministry on 13 January 2010 revealed that this selection of knowledge is very important because bureaucracy could not leave the corridor of law-regulations, including the administrative procedure. He mentioned that such change is very difficult if not initiated by the leader, to be able to see that those law-regulations and administration procedure constitute the problem, and need to be improved. 